\title{
Methods for overcoming seed dormancy in Ormosia arborea seeds, characterization and harvest time ${ }^{1}$
}

\author{
Aparecida Leonir da Silva ${ }^{2 *}$, Denise Cunha Fernandes dos Santos Dias ${ }^{3}$, \\ Liana Baptista de Lima ${ }^{4}$, Glaucia Almeida de Morais ${ }^{5}$
}

\begin{abstract}
Ormosia arborea, a Leguminosae, presents seeds with tegumentary dormancy. The purpose of this study was to evaluate the efficiency of dormancy breaking methods, characterize seeds obtained from different mother plants, and to determine the best period to collect Ormosia arborea seeds. The seeds were harvested from mother plants in two different periods (June and August/2011). The seeds were then subjected to biometrical analyses, determination of moisture content and germination tests. Determination of the soaking curve and evaluation of the dormancy breaking methods were performed using the seeds collected in the second period. The soaking curve confirmed the tegumentary dormancy, and the chemical scarification for 15 minutes was the more adequate procedure to overcome this dormancy. The biometry revealed average values higher than those on literature, and there was difference between both harvesting periods. The mass correlates with the other evaluated parameters, and can be indicated for selecting seeds for seedling production. The two harvesting periods of Ormosia arborea seeds were considered appropriated for seed supplying, due to the high germination potential. Nevertheless, the best period for harvesting is when fruits are already opened, mature, and with low moisture content (no additional drying time needed), what hinders the occurrence of fungi.
\end{abstract}

Index terms: soaking curve, chemical scarification, mechanical scarification.

\section{Métodos para superação da dormência em sementes de Ormosia arborea, caracterização e época de colheita}

\begin{abstract}
RESUMO - Ormosia arborea é uma Leguminosae que apresenta sementes com dormência tegumentar. Objetivou-se avaliar a eficiência de métodos para superação da dormência desta espécie, caracterizar lotes de sementes coletados em diferentes matrizes e determinar a melhor época de coleta. As sementes coletadas de matrizes, em duas épocas (junho e agosto/2011), foram submetidas às análises biométricas, determinação do teor de água e testes de germinação. Com sementes da segunda coleta, determinou-se a curva de embebição e avaliou-se métodos para superação da dormência. A curva de embebição confirmou a dormência tegumentar e a escarificação química por 15 minutos foi o procedimento mais adequado para a superação desta dormência. A biometria revelou valores médios maiores do que os relatados na literatura e houve diferença entre as épocas de coleta. A massa correlacionou-se com os demais parâmetros avaliados, podendo ser indicada para a seleção de sementes na produção de mudas. As duas épocas de coletas de sementes de Ormosia arborea utilizadas foram consideradas adequadas para o fornecimento de sementes, em função do elevado potencial germinativo obtido. Entretanto, a melhor época para a coleta das sementes é quando os frutos já estão abertos, maduros, com baixo teor de água, sem necessidade de secagem adicional, o que dificulta a ocorrência de fungos.
\end{abstract}

Termos para indexação: curva de embebição, escarificação química, escarificação mecânica.

\section{Introduction}

The need to restore the natural environment has set forth a rise in demand for seedlings pertaining to native forest species. Most of these species are dispersed by seeds and the success in seedling formation depends on the knowledge

${ }^{1}$ Submitted on 08/13/2014. Accepted for publication on 09/01/2014.

${ }^{2}$ Departamento de Biologia Vegetal, Universidade Federal de Viçosa, 36570-000-Viçosa, MG, Brasil.

${ }^{3}$ Departamento de Fitotecnia, Universidade Federal de Viçosa, 36570-000-Viçosa, MG, Brasil. about the germination process of each seed as well as the quality of the utilized seed (Rego et al., 2009).

Ormosia arborea (Vell.) Harms belongs to the Fabaceae family and is popularly known as olho-de-cabra (goat eye) (Lorenzi, 2000). These seeds exhibit primary dormancy, which is characterized as the expression of dormancy as

${ }^{4}$ Universidade Federal de Mato Grosso do Sul, Centro de Ciências Biológicas e da Saúde, Laboratório de Botânica, 79070-900-Campo Grande, MS, Brasil ${ }^{5}$ Universidade Estadual de Mato Grosso do Sul, 79740-000- Ivinhema, MS, Brasil.

*Corresponding author:<cida_leonir@hotmail.com> 
soon as its development is complete. The dormancy must be overcome by an efficient method that raises germination rates and enables a greater availability of seedlings, enhancing the use of the species for environmental recovery. Silva and Morais (2012) noted a greater efficacy in seedling emergence of Ormosia arborea when the seeds were scarified in sulfuric acid for 20 minutes. With the intention to produce quality seedlings, a thorough selection of the mother plant is an essential step of the process. The information obtained from monitoring the mother plant provides an indication of the maturation progress and aids in the decision of the best period to begin collecting seeds (Fowler and Martins, 2001).

Until seeds and fruits reach maturity, they undergo several modifications during the maturation process including alteration of their size and shape. Knowledge of the biometry of fruits and seeds is a basic requirement to conserve and explore a plant species. It is also an important tool to detect genetic variability within a population of the same species. The biometry of fruits and seeds can also be used to study the relationship between the genetic variability and environmental factors (Carvalho et al., 2003). Likewise, basic information on germination, cultivation and the potentiality of native species are often demanded for several purposes (Gusmão et al., 2006). This information is essential for comprehending the eco-physiology of the species, its adaptations in the field and to support reforestation programs. However, studies of this nature are scarce and, because of the lack of basic information, the seedling production is often times inefficient.

Seeking to contribute to the seedling production of Ormosia arborea, this study is aimed to evaluate the efficiency of methods to overcome seed dormancy, characterize lots of seeds collected in two distinct periods and to determine the best period for collecting seeds.

\section{Material and Methods}

Seeds of Ormosia arborea were collected from nine mother plants in two different periods (06/16 and 08/06/2011). The mother plants were located at the left riverside of the Ivinhema river, in the city of Nova Andradina, in the state of Mato Grosso do Sul (MS). During the first seed harvest, the fruits were initiating the opening of the pods, but most of them were still closed. In order to fully open the pods of the first lot and release their seeds, the fruits were placed to dry in the sun. In the second harvest, the fruits were already open and the seeds were exposed, remaining sustained by the funiculi.

Soaking curves were built in order to verify if the seed coat was impermeable and how long would it take for the seeds to reach phase II of the germination process. The seeds utilized to build the soaking curves were from the second harvest (which contained more available seeds) and were divided into three groups. The first group contained non-scarified seeds (control group). The second group contained seeds subjected to mechanical scarification and, lastly, the third group contained seeds subjected to chemical scarification (immersion in sulfuric acid for 15 minutes according to Marques et al., 2004). One hundred seeds were utilized for each procedure, which were divided in four replicates of 25 seeds. The soaking curves data were subjected to Kruskal-Wallis test (followed by Dunn test at $5 \%$ of probability). Seeds were immersed in distilled water and kept in a B.O.D. incubator at $25^{\circ} \mathrm{C}$. The mass gain was determined during the entire soaking process. For the first six hours, the gain was determined hourly, then at the 12 hour mark and 24 hour mark. After 24 hours had passed, the determination of mass gain was made every 24 hours until the end of the experiment. Seeds were dried in absorbent paper every time before weighing. Soaking was considered as an increase in mass with respect to the initial mass, and the curve was terminated when the first seed emitted the primary root.

Seeds from nine mother plants of the second seed harvest were utilized to study methods for overcoming seed dormancy. The following treatments were tested: treatments 1 and 2 - mechanical scarification of the seed, using sandpaper number 100 on the opposite side of the hilum, followed by immersion in distilled water for 3 and 5 days, respectively, with daily water renewal. Treatments 3,4 and 5 - chemical scarification of the seeds via immersion into concentrated sulfuric acid $\left(\mathrm{H}_{2} \mathrm{SO}_{4}\right)$ for 15,30 and 45 minutes, respectively, followed by rinsing with running water for 5 minutes. Intact seeds were used as the control group.

Germination experiments were conducted with five replicates of 25 seeds placed inside plastic boxes of the gerbox type. The boxes were filled with $3 / 4$ of vermiculite humidified with $80 \mathrm{~mL}$ of distilled water, and kept in a B.O.D. incubator at $25{ }^{\circ} \mathrm{C}$ for 30 days (Fowler and Martins, 2001) under constant light, adding water when necessary. Seeds that produced a primary root of at least a $2 \mathrm{~mm}$ of length were considered germinated. The germination was assessed daily (Fowler and Martins, 2001). The results were expressed in germination percentage. Using daily data average time, average speed and relative frequency and synchronization index. The average time and average speed were calculated according to Labouriau and Valadares (1976) as follows:

Average time of germination: $t=\frac{\left[\sum_{i=1}^{k} n i . t i\right]}{\sum_{i=1}^{k} n i}$

In which, t: average time of incubation; ni = number of germinated seeds per day; $\mathrm{t} i=$ time of incubation (days). 
Average speed: $V=\frac{1}{t}$

In which: $V=$ average speed of germination; $t=$ average time of germination.

The relative frequency and the synchronization index were calculated according to Labouriau and Pacheco (1978):

Relative frequency: $\operatorname{Fr} \frac{n i}{\sum_{i=1}^{k} n i}$

In which, $\mathrm{Fr}=$ Relative frequency of germination; $\mathrm{ni}=$ number of germinated seeds per day; $\Sigma$ ni $=$ total number of germinated seeds.

Synchronization index or informational entropy of germination: $E=\sum_{i=1}^{k} f i \cdot \log 2 . f i$

In which, $\mathrm{E}=$ synchronization index; fi: relative frequency of germination; $\log _{2=}$ base 2 logarithm.

Treatments were analyzed by Analysis of Variance followed by Tukey test at $5 \%$ of probability. The method considered more efficient was the one that provided a greater germination percentage in less time.

Seeds obtained from both harvests were subjected to the biometric evaluation, moisture content and germination capacity, for the characterization of the lot and determination of the best period for harvesting. With the aid of a digital caliper ruler $(0.01 \mathrm{~mm})$ and precision scale $(0.0001 \mathrm{~g}), 100$ seeds from the mother plant were utilized to determine length, thickness, width and mass.

Frequency distribution of seeds in mass classes, on the first harvest and second harvest, were made with 100 seeds from each mother plant. Length was considered as the longest axis of the seed; width and thickness were obtained at the largest portion of the seed. The biometric data were subjected to Kruskal-Wallis test (followed by Dunn test at 5\% of probability) in order to verify if there was any difference between mother plants from the same harvest.

A $t$ Test at $5 \%$ probability was used to analyze the biometric parameters of seeds from both harvests. The D'Agostino normality test was applied to the distribution of the amplitude of the seeds. The data was evaluated through Spearman's Correlation Coefficient for the existence of correlation between parameters. All tests were performed using the BioEstat 5.3 software.

As described in the Regras para Análise de Sementes (Brasil, 2009), the seeds were incubated at $105{ }^{\circ} \mathrm{C}$ for 24 hours in order to determine the moisture content of the seeds.

After the testing was concluded, the best method to break dormancy was used to scarify seeds from two lots. Each lot was harvested in a distinct period and nine replicates of 50 seeds were used from each harvest. The seeds were placed to germinate according to method previously described here. The average time data was subjected to $t$ Test for two independent samples and to Analysis of Variance.

\section{Results and Discussion}

Non-scarified seeds (control group) had a very low water uptake, with a total gain of $0.13 \mathrm{~g}$ of water after 144 hours. For the mechanical and chemical treatments, the average water uptake was $23.26 \mathrm{~g}$ and $22.79 \mathrm{~g}$, respectively (Figure 1).

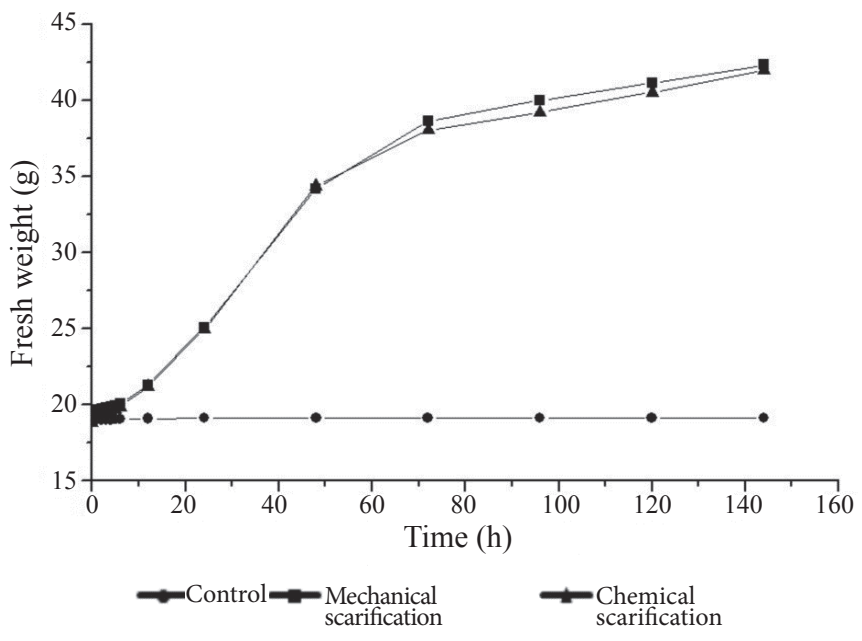

Figure 1. Soaking curves for Ormosia arborea seeds. Scarified and non-scarified seeds.

The water uptake values did not differ significantly between the scarification methods, however both methods statistically differed from the control group $(\mathrm{H}=21.1938 ; p<0.0001)$. Both scarification methods provided an increase of moisture content within 72 hours, and from this point, the protrusion of the primary root was verified for scarified seeds. According to Carvalho and Nakagawa (2000), when a dry seed is exposed to water, a rapid increase in fresh weigh occurs (due to the matric potential). This rapid increase in fresh weight is followed by a slow water absorption, when the main metabolic events of the germination process occur.

Lopes et al. (2004) verified the same imbibition period of 72 hours, at $30{ }^{\circ} \mathrm{C}$, for seeds of Ormosia arborea subjected to mechanical scarification. They also verified the absence of imbibition for intact seeds. Differently, Basqueira et al. (2011) verified that Ormosia arborea seeds subjected to mechanical scarification, showed progressive absorption between one and six hours at $25{ }^{\circ} \mathrm{C}$, stabilizing after that period.

Non-scarified seeds showed an unchanged soaking curve during the entire weighing process, which indicates the presence of an impermeable seed coat. Conversely, scarification eliminated 
the seed coat impermeability, allowing water to be absorbed and the primary root to be emitted after 72 hours, at the end of phase II. According to Perez (2004), members of the Fabaceae family present seeds with an impermeable seed coat which is responsible for preventing water to be absorbed. Bewley et al. (2013) highlighted that in the germination process the imbibition capacity of the seed is fundamental, since a deficiency in water absorption may compromise the function of physiological activities. Thus, for a successful germination it is important to define the best method to break this impermeable seed coat.

Chemical scarification treatments were more effective in breaking dormancy when compared to mechanical scarification. This resulted in high germination percentage with a significant difference in percentage between seeds scarified for 15 and 60 minutes. Mechanical scarification resulted in lower germination percentages, with no significant difference between the two soaking times (Table 1). Non-scarified seeds from the control group did not germinate during the evaluated period.

Table 1. Average time, average speed and synchronization index for the germination of Ormosia arborea seeds subjected to different scarification treatments: T1 - mechanical + water immersion for 3 days; T2 - mechanical + water immersion for 5 days; T3, T4 e T5 - chemical (15, 30 and 60 minutes, respectively). Control - intact seeds.

\begin{tabular}{ccccc}
\hline Treatments & Germination $(\%)$ & Average time (days) & Average speed (days $\left.^{-1}\right)$ & Synchronization index (bits) \\
\hline T1 & $55 \mathrm{~d}$ & $9.656 \mathrm{a}$ & 0.105 & -3.2651 \\
T2 & $57 \mathrm{~cd}$ & $8.239 \mathrm{a}$ & 0.121 & -3.1079 \\
T3 & $91 \mathrm{a}$ & $14.833 \mathrm{a}$ & 0.067 & -4.0088 \\
T4 & $82 \mathrm{ab}$ & $13.215 \mathrm{a}$ & 0.076 & -3.8582 \\
T5 & $71 \mathrm{bc}$ & $14.326 \mathrm{a}$ & 0.070 & -3.8411 \\
\hline Control & 0 & $0 \mathrm{~b}$ & 0 & 0 \\
CV\% & 23.4 & & 0 \\
\hline
\end{tabular}

Averages followed by the same letter, did not differ statistically from each other by Tukey test at $5 \%$ probability.

In a study conducted by Lopes et al. (2004), chemical scarification also provided high germination percentages in seeds of Ormosia arborea, whereas mechanical scarification did not differ from control. Teixeira et al. (2009) and Gonçalves et al. (2011) also verified the greater efficiency of chemical scarification, however chemical scarification did not significantly differ from mechanical scarification using sandpaper in the latter study. Marques et al. (2004) recommended both procedures for breaking dormancy in Ormosia arborea seeds. Conversely, Lorenzi (2000) only indicated the mechanical scarification method to promote seed germination in this species. He reported a germination rate of over $50 \%$, with emergence occurring in 20-50 days. Fowler and Martins (2001) also recommended the mechanical scarification method using sandpaper.

In this study, approximately $37 \%$ of the mechanically scarified seeds were contaminated by fungi and did not germinate, whereas for chemically scarified seeds this loss was only $7 \%$. Similar results were found by Lopes et al. (2004) where fungi deteriorated about $48 \%$ of the seeds that were mechanically scarified and pre-imbibed for 24 hours.

The average germination time varied from 8.239 day (T2) to 14.833 days (T3). These treatments exhibited the highest and lowest synchrony, respectively. The frequency distribution graphs (Figure 2) revealed a tendency of displacement to the left in T2 and T1, with the lowest values of average time (although without significant difference from other treatments) and highest values of synchrony (Table 1).

In the first and second harvests, the respective average values of length (12.9 and $12.4 \mathrm{~mm}$ ), thickness ( 8.5 and $8.3 \mathrm{~mm}$ ), width (11.3 and $11.1 \mathrm{~mm}$ ) and mass ( 0.827 and $0.776 \mathrm{~g}$ ) were greater than those reported by Gurski et al. (2012) for Ormosia arborea seeds (11.5 mm; $7.5 \mathrm{~mm}$ and $9.2 \mathrm{~mm}$ ) (Table 2$)$.

A significant difference $(p<0.0001)$ in seed biometry collected from different mother plants was found for both the first and the second for all parameters, considering general average seeds from the second harvest had statistically lower values when compared to those from the first. Mass proved to be the most heterogeneous measurement with a higher coefficient of variation, while length proved to be the most stable measurement (Table 2). This variation in seed biometry occurred between individuals from the same species, and frequently in seeds originated from the same individual (Vaughton and Ramsey, 1998).

Analyzing the mass frequency distribution of the seeds, the most frequent groups were those containing seeds of 0.651 $0.75 \mathrm{~g}$ and $0.751-0.85 \mathrm{~g}$ (Figure 3 ). The difference between harvests was caused by the decrease in sample variation however the second harvest showed higher uniformity of seed mass and a normal distribution (Figure 3). The minimum and maximum values obtained from each mother plant show that the amplitude variation can be high for seeds within the same mother plant and therefore none of the mother plants had exclusively large or small seeds (Table 2 and Figure 3). 

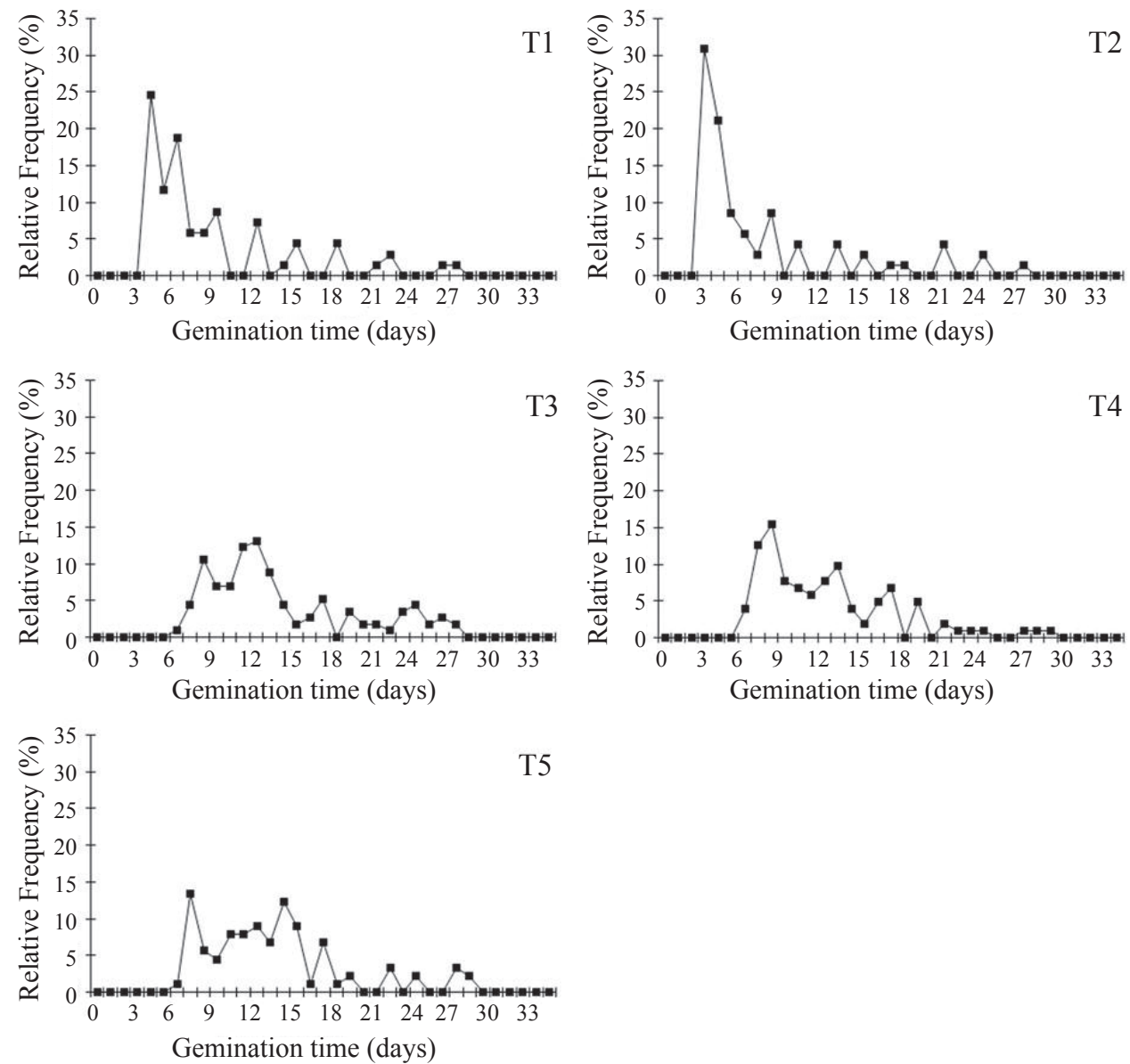

Figure 2. Relative frequency polygons for the germination of Ormosia arborea seeds subjected to different scarification treatments: T1 - mechanical + immersion in water for 3 days; T2 - mechanical + immersion in water for 5 days; T3, T4 e T5 - chemical (15, 30 and 60 minutes, respectively).

Table 2. Biometrical data of Ormosia arborea seeds: length, thickness and width in millimeters and mass in grams.

\begin{tabular}{ccccccccc}
\hline \multirow{2}{*}{ Mother plant } & \multicolumn{2}{c}{ Length } & \multicolumn{2}{c}{ Thickness } & \multicolumn{2}{c}{ Width } & \multicolumn{2}{c}{ Mass } \\
\cline { 2 - 8 } & $1^{\mathrm{a}}$ Harvest & $2^{\mathrm{a}}$ Harvest & $1^{\mathrm{a}}$ Harvest & $2^{\mathrm{a}}$ Harvest & $1^{\mathrm{a}}$ Harvest & $2^{\mathrm{a}}$ Harvest & $1^{\mathrm{a}}$ Harvest & $2^{\mathrm{a}}$ Harvest \\
\hline 1 & $11.96 \mathrm{e}$ & $11.85 \mathrm{e}$ & $8.32 \mathrm{bc}$ & $8.24 \mathrm{cde}$ & $10.30 \mathrm{e}$ & $10.23 \mathrm{~d}$ & $0.70 \mathrm{bc}$ & $0.69 \mathrm{~b}$ \\
2 & $13.21 \mathrm{c}$ & $12.65 \mathrm{~b}$ & $9.14 \mathrm{a}$ & $9.06 \mathrm{a}$ & $11.48 \mathrm{c}$ & $11.42 \mathrm{~b}$ & $0.92 \mathrm{a}$ & $0.88 \mathrm{a}$ \\
3 & $11.93 \mathrm{e}$ & $11.87 \mathrm{de}$ & $8.41 \mathrm{~b}$ & $8.26 \mathrm{cde}$ & $10.74 \mathrm{~d}$ & $10.80 \mathrm{c}$ & $0.71 \mathrm{~b}$ & $0.70 \mathrm{~b}$ \\
4 & $14.11 \mathrm{a}$ & $13.27 \mathrm{a}$ & $8.88 \mathrm{a}$ & $8.47 \mathrm{bc}$ & $12.03 \mathrm{~b}$ & $11.45 \mathrm{~b}$ & $0.99 \mathrm{a}$ & $0.89 \mathrm{a}$ \\
5 & $13.75 \mathrm{ab}$ & $12.68 \mathrm{~b}$ & $9.17 \mathrm{a}$ & $8.63 \mathrm{~b}$ & $13.06 \mathrm{a}$ & $12.41 \mathrm{a}$ & $1.05 \mathrm{a}$ & $0.91 \mathrm{a}$ \\
6 & $13.39 \mathrm{bc}$ & $12.50 \mathrm{bc}$ & $8.96 \mathrm{a}$ & $8.38 \mathrm{bd}$ & $12.75 \mathrm{ab}$ & $12.15 \mathrm{a}$ & $1.01 \mathrm{a}$ & $0.87 \mathrm{a}$ \\
7 & $11.97 \mathrm{e}$ & $12.00 \mathrm{de}$ & $8.35 \mathrm{bc}$ & $8.23 \mathrm{de}$ & $10.64 \mathrm{de}$ & $10.91 \mathrm{c}$ & $0.70 \mathrm{bc}$ & $0.72 \mathrm{~b}$ \\
8 & $13.16 \mathrm{c}$ & $12.70 \mathrm{~b}$ & $7.13 \mathrm{~d}$ & $7.08 \mathrm{f}$ & $10.39 \mathrm{de}$ & $10.14 \mathrm{~d}$ & $0.64 \mathrm{c}$ & $0.61 \mathrm{c}$ \\
9 & $12.42 \mathrm{~d}$ & $12.20 \mathrm{~cd}$ & $8.07 \mathrm{c}$ & $8.10 \mathrm{e}$ & $10.64 \mathrm{de}$ & $10.65 \mathrm{c}$ & $0.72 \mathrm{~b}$ & $0.72 \mathrm{~b}$ \\
General Average & $12.88 \mathrm{~A}$ & $12.41 \mathrm{~B}$ & $8.49 \mathrm{~A}$ & $8.27 \mathrm{~B}$ & $11.34 \mathrm{~A}$ & $11.13 \mathrm{~B}$ & $0.83 \mathrm{~A}$ & $0.78 \mathrm{~B}$ \\
Maximum & 16.18 & 14.56 & 11.55 & 10.76 & 15.50 & 14.10 & 1.67 & 1.34 \\
Minimum & 9.43 & 10.21 & 4.59 & 5.66 & 8.76 & 8.31 & 0.33 & 0.40 \\
Coefficient of & $7.97 \%$ & $6.39 \%$ & $9.56 \%$ & $8.48 \%$ & $10.47 \%$ & $8.64 \%$ & $22.45 \%$ & $17.77 \%$ \\
variation & 1.026 & 0.793 & 0.812 & 0.701 & 1.187 & 0.961 & 0.186 & 0.138 \\
Standard Deviation & 557.483 & 302.379 & 510.718 & 387.439 & 608.519 & 556.932 & 634.766 & 558.854 \\
H= & & & & & & & &
\end{tabular}

Mean values followed by the same letter did not differ statistically from each other at $5 \%$ probability by test $t$ : lowercase between column, and uppercase between row. 

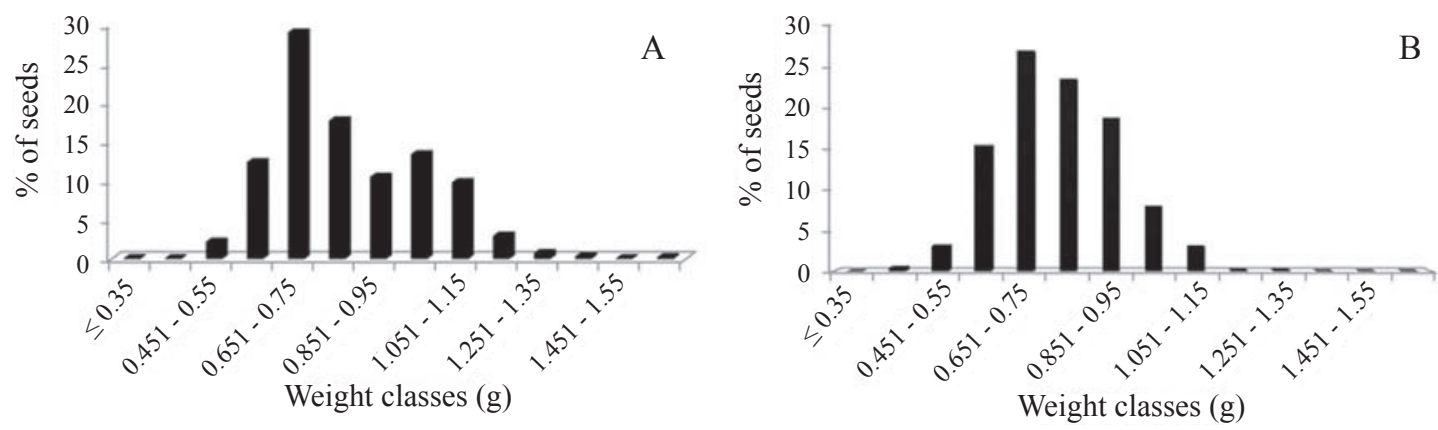

Figure 3. Frequency distribution of Ormosia arborea seeds in mass classes: A. First harvest; B. Second harvest.

This is an important aspect for mother plant selection. According to Fontenele et al. (2007), the difference between minimum and maximum values allows us to explore the genetic variability of features. This exploration focus on the maintenance of areas with representative populations of this species and its genetic variability

According to the correlation analysis (Table 3), a significant relation between mass and the other measurements such as length, thickness and width, was found. The following significant correlations, in that order, had decreasing values in both harvests: width $\mathrm{x}$ mass; thickness $\mathrm{x}$ mass; length $\mathrm{x}$ mass; and thickness $\mathrm{x}$ width. There was no significant correlation between length and thickness of seeds.

Table 3. Spearman's correlation $\left(\mathrm{r}_{\mathrm{s}}\right.$ ) for biometric variables of Ormosia arborea seeds from the first and second harvest.

\begin{tabular}{lcl}
\hline & $1^{\text {a } H a r v e s t}$ & $2^{\text {a }}$ Harvest \\
\cline { 2 - 3 } & \multicolumn{1}{c}{$\mathrm{r}_{\mathrm{s}}$} & \multicolumn{1}{c}{$\mathrm{r}_{\mathrm{s}}$} \\
\hline length $\mathrm{x}$ thickness & 0.3658 & 0.1548 \\
length $\mathrm{x}$ width & $0.5971^{* *}$ & 0.3522 \\
length $\mathrm{x}$ mass & $0.6928^{* *}$ & $0.5718^{* *}$ \\
thickness $\mathrm{x}$ width & $0.6529^{* *}$ & $0.4744^{* *}$ \\
thickness x mass & $0.8218^{* *}$ & $0.7476^{* *}$ \\
width x mass & $0.8654^{* *}$ & $0.8099^{* *}$ \\
\hline
\end{tabular}

**Highly significant considering $p$ value.

The minimum moisture content observed, considering all mother plants, was $6.80 \%$ and the maximum was $27.40 \%$. The mean value for the first harvest was $13.05 \%$ and for the second harvest $11.64 \%$. There was a slight reduction of moisture content in seeds collected from open fruits. Due to this reduction a difference in the average values of seed dimension could be observed between the different harvests (Table 2), in which the values were lower for the second harvest. However, other environmental factors cannot be discarded as well as climatic conditions and physiological aspects. This water loss represents a pre-programmed phase of drying (or desiccation) in seed maturation, also a feature of orthodox seeds (Castro et al., 2004).

Based on the germination test (Table 1), the most efficient method to break dormancy was the chemical scarification in sulfuric acid for 15 minutes. This method was utilized to evaluate the germination capacity of lots collected in different periods. The germination percentages of Ormosia arborea were $89 \%$ for the first harvest and $98 \%$ for the second harvest (Table 4). These values were higher than those found by Lopes et al. (2004) (61\%) for the same species subjected to the same immersion period of 15 minutes in acid, but at $30^{\circ} \mathrm{C}$. This difference can be caused by genetic and environmental factors related to the mother plant, which results in different responses. Aspects such as, lot origin, period of harvest and distinct conditions of experimentation can also affect the final results (Perez, 2004).

Thus, with the intention to reduce fungi growth, and consequently seed loss, as well as to facilitate seed storage, the best period observed to harvest seeds from this species was at end of the desiccation phase, which is characterized by spontaneous fruit opening.

When the germination data (Table 4) is compared with the average biometry of the seeds by harvest period (Table 2), it was observed that seeds with larger dimensions did not necessarily present higher percentage of germination. According to Carvalho and Nakagawa (2000), the germination is not influenced by seed size, which would affect the seedling vigor, but it is dependent on other factor such as viability, climatic conditions, etc. A plant originated from a small seed would have its growth retarded in the beginning, whereas after this initial growth the plant would recover reaching its normal growth (Carvalho and Nakagawa, 2000).

The data related to seed biometry, specially the mass, could help the selection of seeds for an efficient seedling establishment and would determine the success in the growth 
of the plants. The fast emergence of seedlings from heavier seeds was verified by Parker et al. (2006) for Pinus strobus
L. (Pinaceae), although under laboratorial conditions the difference in seed mass did not influence the germination.

Table 4. Average time, average speed and synchronization index for the germination of Ormosia arborea seeds from the first and second harvest.

\begin{tabular}{ccccc}
\hline & $\begin{array}{c}\text { Germination }^{\text {ns }} \\
(\%)\end{array}$ & $\begin{array}{c}\text { Average time }^{\text {ns }} \\
(\text { days })\end{array}$ & $\begin{array}{c}\text { Average speed } \\
\left(\text { days }^{1}\right)\end{array}$ & $\begin{array}{c}\text { Synchronization Index } \\
(\text { bits })\end{array}$ \\
\hline $1^{\text {a }}$ Harvest & 89 & 10.995 & 0.090 & -3.5143 \\
$2^{\text {a }}$ Harvest & 98 & 14.786 & 0.067 & -4.2459 \\
\hline
\end{tabular}

*significant difference by test $t$ at $5 \%$ probability; ${ }^{\text {ns }}$ no significant difference by test $t$ at $5 \%$ probability.

The average germination time was 10.995 days for the first harvest and 14.786 days for the second harvest, with no significant difference between both harvest periods (Table 4).

Conversely from what was found by Oliveira et al. (2008) for another Leguminosae species, the germination percentage of Ormosia arborea seeds was high (independent from harvest period) and there was no significant difference in the average percentage.

\section{Conclusions}

The chemical scarification by immersion in sulfuric acid for 15 minutes is efficient for dormancy breaking of Ormosia arborea seeds.

Both harvesting periods utilized for this study were considered adequate for seed supplying, due to the high germination potential achieved under laboratorial conditions. Nevertheless, the best period for harvesting is when the fruits are already opened and the seeds exposed. Hence the seeds will not need any additional drying time and will be less susceptible to fungi attack due to the lower moisture content of the seed.

\section{Acknowledgements}

We thank Prof. Dr. Douglas de Araujo for revising the text.

\section{References}

BASQUEIRA, R.A.; PESSA, H.; SOUZA-LEAL, T.; PEDROSO-DEMORAES, C. Superação de dormência em Ormosia arborea (Fabaceae: Papilionoideae) pela utilização de dois métodos de escarificação mecânica em diferentes pontos do tegumento. Revista em Agronegócios e Meio Ambiente, v.4, n.3, p.547-561, 2011. http://www.cesumar.br/pesquisa/periodicos/index. $\mathrm{php} / \mathrm{rama} /$ article/view/1876/1301

BEWLEY, J.D.; BRADFORD, K.J., HILHORST, H.W.M.; NONOGAKI, H. Seeds: Physiology of Development, Germination and Dormancy. New York: Plenum, 2013. 392p.
BRASIL. Ministério da Agricultura, Pecuária e Abastecimento. Regras para análise de sementes. Ministério da Agricultura, Pecuária e Abastecimento. Secretaria de Defesa Agropecuária. Brasília: MAPA/ACS, 2009. 395p. http:// www.bs.cca.ufsc.br/publicacoes/regras\%20analise $\% 20$ sementes.pdf

CARVALHO, N.M; NAKAGAWA, J. Sementes: ciência, tecnologia e produção. 4 ed. Campinas: Fundação Cargill, 2000. 588p.

CARVALHO, J.E.U.; NAZARÉ, R.F.R.; OLIVEIRA, W.M. Características físicas ou físico-químicas de um tipo de bacuri (Platonia insignis Mart.) com rendimento industrial superior. Revista Brasileira de Fruticultura, v.25, n.2, p.326-328, 2003. http://www.scielo.br/scielo.php?script=sci arttext\&pid=S0100-29452003000200036

CASTRO, R.D.; BRADFORD, K.J.; HILHORST, H.W.M. Desenvolvimento de sementes e conteúdo de água. In: FERREIRA, A.G.; BORGHETTI, F. (Orgs.) Germinação: do básico ao aplicado. Porto Alegre: Artmed, 2004. p. 51-67.

FONTENELE, A.C.F.; ARAGÃO, W.M.; RANGEL, J.H.A. Biometria de frutos e sementes de Desmanthus virgatus (L) Willd nativas de Sergipe. Revista Brasileira de Biociencias, v.5, n.1, p.252-254, 2007. www.ufrgs.br/ seerbio/ojs/index.php/rbb/article/download/275/244

FOWLER, A.P.; MARTINS, E.G. Manejo de sementes de espécies florestais Colombo: Embrapa Florestas, 2001. 71p. (Embrapa Florestas. Documentos, 58). www.infoteca.cnptia.embrapa.br/bitstream/doc/289390/1/doc58.pdf

GONÇALVES, E.P.; SOARES, F.S.J.; SILVA, S.S.; TAVARES, D.S.; VIANA, J.S.; CARDOSO, B.C.C. Dormancy Breaking in Ormosia arborea Seeds. International Journal of Agronomy, v.2011, 5p., 2011. http://www hindawi.com/journals/ija/2011/524709

GURSKI, C.; DIAS, E.S.; MATTOS, E.A. Caracteres das sementes, plântulas e plantas jovens de Ormosia arborea (Vell.) Harms e Ormosia fastigiata Tul. (Leg-papilionoideae). Revista Árvore, v.36, n.1, p.37-48, 2012. http://www. scielo.br/scielo.php?pid=S0100-67622012000100005\&script=sci_arttext

GUSMÃO, E.; FILHO, S.M.; VIEIRA, F.A.; JUNIOR, E.M.F. Biometria de frutos e endocarpos de murici (Byrsonima verbascifolia Rich.ex A Juss). Cerne, v.12, n.1, p.84-91, 2006. http://redalyc.uaemex.mx/src/inicio/ ArtPdfRed.jsp?iCve $=74412110$

LABOURIAU, L.G.; PACHECO, A. On the frequency of isotherma germination in seeds of Dolichos biflorus L. Plant and Cell Physiology, v.21, p.507-512, 1978. http://pcp.oxfordjournals.org/content/19/3/507.abstract

LABOURIAU, L.G.; VALADARES, M.E.B. On the germination of seeds of Calotropis procera (Ait.) Ait. F. Anais da Academia Brasileira de Ciências, v.48, p. 263-284, 1976. 
LOPES, J.C.; DIAS, P.C.; MACEDO, C.M.P. Tratamentos para superar a dormência de sementes de Ormosia arborea (Vell.) Harms. Brasil Florestal, n.80, p.25-35, 2004. http://www.researchgate.net/profile/ Paulo_Dias15/publication/263182712_Tratamentos_para_superar_a_ dormncia_de_sementes_de_Ormosia_arborea_\%28Vell.\%29_Harms/ links/0f31753a1aefa8bc4a000000

LORENZI, H. Árvores Brasileiras: Manual de Identificação e Cultivo de Plantas Arbóreas Nativas do Brasil. 3. ed. Nova Odesssa/SP: Instituto Plantarum, 2000. 352p.

MARQUES, M.A.; RODRIGUES, T.J.D.; PAULA, R.C. Germinação de sementes de Ormosia arborea (Vell.) Harms submetidas a diferentes tratamentos pré-germinativos. Cientifica, v.32, n.2, p.141-146, 2004. www. cientifica.org.br/index.php/cientifica/article/download/79/62

OLIVEIRA, D.A.; NUNES, Y.R.F.; ROCHA， E.A.; BRAGA， R.F.; PIMENTA, M.A.S.; VELOSO, M.D.M. Potencial germinativo de sementes de fava-d'anta (Dimorphandra mollis Benth. - FABACEAE: MIMOSOIDEAE) sob diferentes procedências, datas de coleta e tratamentos de escarificação. Revista Árvore, v.32, n.6, p.1001-1009, 2008. http://www.scielo.br/scielo. php?script $=$ sci_arttext\&pid=S0100-67622008000600005

PARKER, W.C.; NOLAND, T.L. MORNEAULT, A.E. The effects of seed mass on germination, seedling emergence, and early seedling growth of eastern white pine (Pinus strobus L.). New Forests, v.32, n.1, p.33-49, 2006. http://link.springer.com/article/10.1007\%2Fs11056-005-3391-1\#page-1
PEREZ, S.C.J.G.A. Envoltórios. In: FERREIRA, A.G.; BORGHETTI, F. (Orgs.). Germinação: do básico ao aplicado. Porto Alegre: Artmed, 2004. p.125-134.

REGO, S.S.; NOGUEIRA, A.C.; KUNIYOSHI, Y.S.; SANTOS, A.F. Germinação de sementes de Blepharocalyx salicifolius (H.B.K.) Berg. em diferentes substratos e condições de temperaturas, luz e umidade. Revista Brasileira de Sementes, v.31, n.2, p.212-220, 2009. http://www.scielo.br/ scielo.php?pid=S0101-31222009000200025\&script $=$ sci_arttext

SILVA, A.L.; MORAIS, G.A. Biometry and dormancy breaking of Ormosia arborea seeds. Communications in Plant Sciences. Lages, v.2, p.3-4, 2012 http://complantsci.files.wordpress.com/2012/12/complantsci 2 2 22.pdf

TEIXEIRA, W.F.; RODRIGUES, E.A.; AMARAL, A.F. Estudo de superação de dormência de Ormosia arborea sob diferentes testes, para produção de mudas para reflorestamento de áreas degradadas no município de Patos de Minas, MG. Perquirere - Revista do Núcleo Interdisciplinar de Pesquisa e Extensão do UNIPAM, n.6, p.26-30, 2009. http://www.unipam.edu.br/ perquirere/file/file/2009/Estudo_de_superacao_de_dormencia.pdf

VAUGHTON, G.; RAMSEY, M. Sources and consequences of seed mass variation in Banksia marginata (Proteaceae). Journal of Ecology, v.86, p.63573, 1998. http://www.jstor.org/discover/10.2307/2648421?uid=3737664\&u id $=2129$ \&uid $=2 \&$ uid $=70$ \&uid $=4 \&$ sid $=21101639546833$ 